\title{
Geochemistry and fluid-inclusion microthermometry of the Farsesh barite deposit, Iran
}

\author{
Alireza Zarasvandi ${ }^{1 *}$, Nazanin Zaheri ${ }^{1}$, Houshang Pourkaseb ${ }^{1}$, \\ Abbas Chrachi ${ }^{1}$, Hashem Bagheri ${ }^{2}$ \\ ${ }^{1}$ Department of Geology, Shahid Chamran University (SCU), Ahvaz, Iran \\ ${ }^{2}$ Department of Geology, Isfahan University, Isfahan, Iran \\ *corresponding author, e-mail: zarasvandi_a@scu.ac.ir
}

\begin{abstract}
The Permian carbonate-hosted Farsesh barite deposit is located southeast of the City of Aligudarz in the province of Lorestan, Iran. Structurally, this deposit lies in the Zagros metallogenic belt and the Sanandaj-Sirjan Zone. Barite mineralisations occur as open-space filling veins, and as massive and replacement ores along fractures, faults and shear zones of the Permian carbonate host rocks. In order to determine the structure, in addition to petrographic and fluid-inclusions studies, an ICP-MS analysis was carried out in order to measure the major as well as the trace and rare earth elements. The Farsesh barite deposit has a simple mineralogy, of which barite is the main mineral, followed by calcite, dolomite, quartz, and opaque minerals such as Fe-oxides. Replacement of barite by calcite is common and is more frequent than space-filling mineralisation. Sulphide minerals are minor and mainly consist of chalcopyrite and pyrite, which are altered by weathering to covellite, malachite and azurite.

Petrographic analysis and micro-thermometry were carried out on the two-phase liquid/vapour inclusions in ellipsoidal or irregularly shaped minerals ranging in size from 5-10 $\mu \mathrm{m}$. The measurements were conducted on fluid inclusions during the heating and subsequent homogenisation in the liquid phase. The low homogenisation temperatures $\left(200-125^{\circ} \mathrm{C}\right)$ and low to moderate salinity $(4.2-20$ eq $\mathrm{wt} \% \mathrm{NaCl})$ indicate that the barite had precipitated from hydrothermal basinal water with low to moderate salinity. It appears from the major and trace elements that geochemical features such as Ba and Sr enrichment in the barite samples was accompanied by depletion of $\mathrm{Pb}, \mathrm{Zn}, \mathrm{Hg}, \mathrm{Cu}$ and $\mathrm{Sb}$. The geochemistry of the rare earth elements, such as low $\Sigma$ REE concentrations, LREE-enrichment chondrite-normalised REE patterns, the negative Ce and positive Eu anomalies, the low Ce/La ratio and the positive La and Gd anomalies, suggest that the Farsesh barite was deposited from hydrothermally influenced sea water. The Farsesh deposit contains low-temperature hydrothermal barite. The scatter plots of the barite (close to sea water) in different areas on the $\mathrm{Ce}_{\mathrm{N}} / \mathrm{Sm}_{\mathrm{N}}$ versus $\mathrm{Ce}_{\mathrm{N}} / \mathrm{Yb}_{\mathrm{N}}$ diagram support the possibility that the barite was formed from seawater-bearing hydrothermal fluids.
\end{abstract}

Key words: hydrothermal barite, ICP-MS analysis, geochemistry, fluid inclusions, Sanandaj-Sirjan Zone, Iran

\section{Introduction}

More than 100 barite deposits have been identified in Iran. Their ages range, as implied from datings of their host rocks, from Late Precambrian to Miocene (Ghorbani, 2002). A wide variety of barite mineralisations in Tertiary volcanic rocks occur in association with volcano-sedimentary successions in the southern Central Alborz Mountain
Range (Azerbaijan) and in the Urumieh-Dokhtar Magmatic Arc (U-DMA) (Ehya, 2012). Barite mineralisation in dolomitic rocks is widespread in central Iran, the Alborz Mountain Range and the Sanandaj-Sirjan Zone (SSZ) (Ghorbani, 2002). Permian and Cretaceous barite deposits occur mainly in the SSZ and central Iran, chiefly near $\mathrm{Pb}$ and $\mathrm{Zn}$ deposits (Ghorbani, 2002). Palaeozoic carbonate-hosted barite deposits are widespread 
in the region around the eastern part of Lorestan province, which is situated in the SSZ. The most important barite deposits in this region are associated with Permian dolomitic limestones or older sediments. Barite exploration by the Geological Survey Institute of Iran has shown that Permian dolomitic limestones host many of the barite north-west and north-east of the village of Farsesh.

There are no detailed studies on this barite mineralisation along the Sanandaj-Sirjan Zone; the present work focuses on the Farsesh deposit, which is located in the western part of the province of Isfahan near the eastern part of its border with the province of Lorestan (Fig. 1). It is approx. $45 \mathrm{~km}$ south-east of Aligudarz, a town in the easternmost part of Lorestan. It is an example of the Permian carbonate-hosted barite deposits in the SSZ. Because little is known about the factors controlling the genesis of the Farsesh barite deposit, the present study reports on the detailed geological investigations, including field geology, ore microscopy, fluid-inclusion analysis and the geochemistry of major, trace and rare earth elements in the host rock
, as well as on the barite mineralisation. Fluid-inclusion microthermometry and rare earth element (REE) geochemistry can potentially serve as indicators of the physico-chemical environment of barite mineralisation in the region around the eastern part of Lorestan and in similar geological settings.

\section{Geology}

Iran is situated roughly in the middle of the Alpine-Himalayan orogenic belt (Molinaro et al., 2005). The Zagros orogen forms part of this orogenic belt which is $200-350 \mathrm{~km}$ wide and composed of a series of mountain ranges that extend over about $1500 \mathrm{~km}$ from south-eastern Turkey to Iran (Safaei, 2009) and consists of three major tectonic zones (Fig. 1): the Urumieh-Dokhtar Magmatic Arc belt (U-DMA), the Sanandaj-Sirjan Zone (SSZ); and the Zagros fold-thrust belt (ZFTB) (Alavi, 1994, 2004; Ghasemi and Talbot, 2006; Yeganeh et al., 2012). The SSZ is roughly $1500 \mathrm{~km}$ long and 150-200 wide, and has experienced several metamorphism, defor-

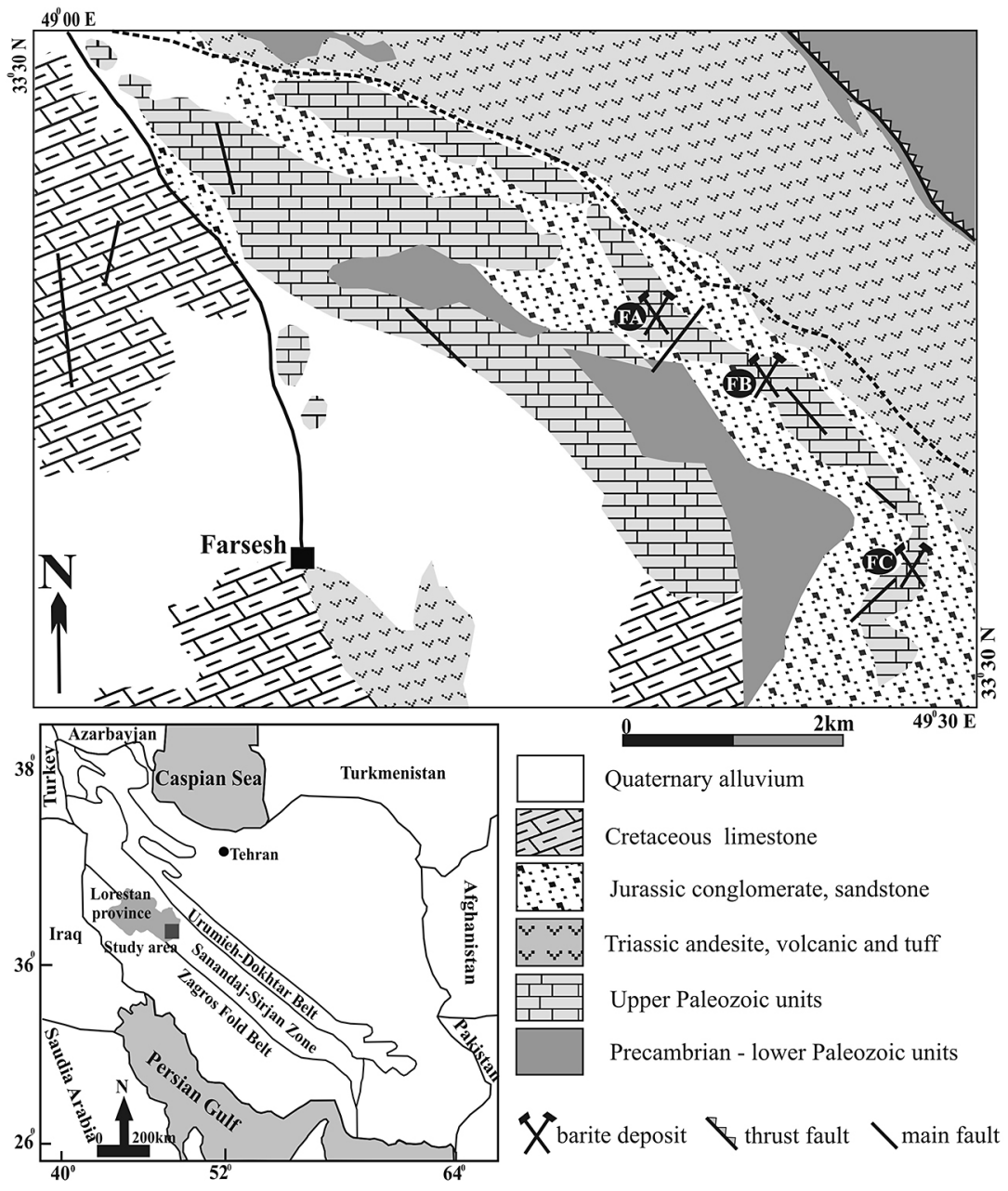

Fig. 1. Main tectonic zones of Iran (modified from Alavi, 2004, after Zarasvandi et al., 2008) and simplified geological map of the Farsesh barite deposit (modified after Sohieli et al., 1992) 
mation and magmatism events from the Palaeozoic to the Eocene (Aliyari et al., 2012).

The study area is located in the south-east of the town of Aligudarz, near the village of Farsesh, which is geologically and structurally in the marginal subzone of the Sanandaj-Sirjan Zone (Mohajjel et al., 2003). This sub-zone is characterised by features such as uninterrupted Jurassic to Cretaceous deposition, Late Jurassic to Early Cretaceous volcanic activity and shallow-marine successions (Mohajjel et al., 2003).

Non-metamorphosed Middle and Late Palaeozoic carbonates occur in the Aligudarz area.The oldest rock units outcropping in the Farsesh area are Precambrian to Early Palaeozoic units (Fig. $1)$; these include amphibolite schists, mica schists, marbles, fine-grained quartzites and acidic to basic metavolcanic formations (Soheili et al., 1992). Late Palaeozoic units include Devonian shales, sandstones and limestones north of the Farsesh area and Carboniferous-Permian dolomitic limestones to the north-east and east of the area. Permian limestones are indicative of Tethys rifting in the deformation history of the SSZ (Mohajjel et al., 2003). Barite mineralisation in the Farsesh deposit occurred in the Permian dolomitic limestone beside Late Triassic-Jurassic andesites in the south-eastern part of the Aligudarz region. Extensional rifting took place in the SSZ (Ghasemi \& Talbut, 2006), particularly in the Farsesh area, during the Permian to Middle-Late Triassic.

Triassic andesitic volcanic rocks and calcareous andesitic tuffs are exposed in the northern part of the study area. The Middle to Late Triassic-Jurassic andesites and andesitic tuffs in the northern part of study area originated due to subduction of the Neotethys oceanic crust and volcanic island-arc collision in the Permian zone (Darvishi, 2011). No geological or genetic relationships have been found between these volcanic and the barite mineralisation in the Farsesh area (Soheili et al., 1992). Late Jurassic to Early Cretaceous andesitic lavas are the only volcanic features in the whole Sanandaj-Sirjan Zone (Mohajjel et al., 2003). Overlying these volcanic rocks are Jurassic shallow-marine conglomerates, sandstones and shales, and Early Cretaceous clastic and bioclastic sediments. Late Cretaceous progressive low-grade metamorphism affected the Early Cretaceous conglomerates of the marginal sub-zone (Mohajjel et al., 2003).

\section{Barite mineralisation}

Palaeozoic carbonate-hosted barite deposits are widely spread in the region around the eastern part of Lorestan. This region includes the northern and north-eastern parts of the Farsesh area, where Permian dolomitic limestone hosts the barite. The Farsesh deposit includes three small prospects of barite mineralisation (FA, FB, FC), which are located 1-2 km from each other in a NW-SE trend (Fig. 1).

Field observations indicate that the Farsesh mineralisation occurs along faults and fractures in the form of veins and massive bodies, and in some areas as replacement textures in the Permian carbonates (Fig. 2A-C). Other sulphide minerals are also present and include chalcopyrite, pyrite, covellite, malachite and azurite. One of the most remarkable features in these ore deposits is the presence of iron oxides in association with the barite ores. $\mathrm{Cu}$-minerals such as malachite and azurite are the most abundant minerals resulting from surface oxidation (Fig. 2D).

Petrographic analysis shows that the mineralogy of the deposit is relatively simple. It consists of barite as the main mineral, together with quartz, calcite and dolomite, and small amounts of Fe-oxides and other opaque minerals (Fig. 3). Microscopic studies indicate that barite mineralisation occurs in different shapes. Coarse and long grains of barite show replacement of barite in the host-rock of dolomitic limestone, and as joint infillings. These studies also reveal secondary replacement of barite as a result of tectonic activity and circulation of ore-bearing solutions through the carbonate host rock. The mineralogical assemblage of the deposit suggests that coarse, elongated barite crystals acted as replacement forms, whereas blade-shaped and crushed fine crystals of barite mostly occur as vein-filling textures. Euhedral to subhedral tabular barite was replaced by calcite. Calcite, which is the second most common mineral, generally forms intergrowths with barite (Fig. 2E). The abundance of calcite and dolomite inclusions in the space-filling barites indicates that the replacement of calcite by barite is a common phenomenon. Quartz crystallises together with barite along fissures during the mineralisation process (Fig. 2G). The contact between ore and host rock is characterised by the formation of opaque minerals in the fractures, which indicates the last stage of mineralisation. Iron oxides are also found as small patches in some samples. Base-metal sulphides are rare in the Farsesh barite deposit; chalcopyrite and very minor amounts of pyrite are present (Fig. 2H, I). Post-mineralisation weathering of these primary sulphides has produced malachite, azurite and covellite. The covellite can be seen as a pale blue halo around the chalcopyrite (Fig. 2H). Field evidence shows a relationship between the host rock and various forms of barite mineralisa- 


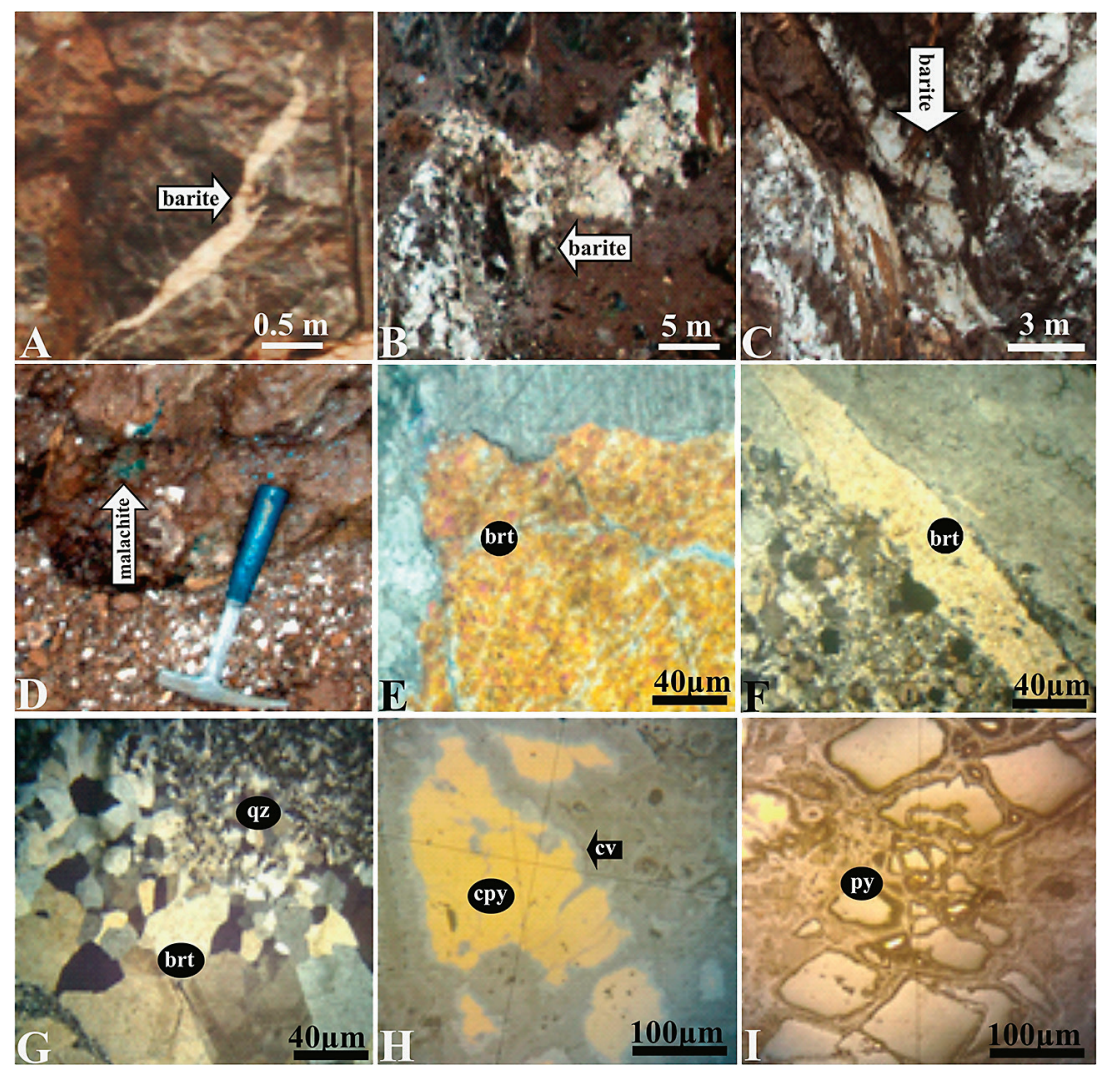

Fig. 2. Different styles and ore occurrences of barite mineralisation $(\mathrm{a}-\mathrm{d})$, and thin $(\mathrm{e}-\mathrm{g})$ and polished sections (h and i) of samples rom the Farsesh barites (plane-polarised transmitted and reflected light)

A: White barite veins in the Permian dolomitic limestone; B: Massive white barite mineralisations as cavity infillings by dissolution of dolostone; C: Replacement of barite mineralisation along fault zones and as ore-filled breccia zones; D: Surfacial mineralisation of copper carbonates (green: malachite); E: Barite (brt) replacement by coarse-grained dolomite; F: Replacement of coarse-grained blade-shaped euhedral tabular barite (brt) by calcite; G: Finegrained subhedral barite (brt) and quartz (qz) (greyish white); H: Coarse-grained and subhedral chalcopyrite (срy) that altered to covellite (cv); I: Coarse-grained and euhedral to subhedral pyrite (py).

\begin{tabular}{|r|l|l|l|}
\hline mineral & pre-mineralisation & mineralisation & post-mineralisation \\
\hline barite & & - & \\
\hline quartz & & & \\
\hline calcite & & & \\
\hline dolomite & & & \\
\hline iron oxides & & & - \\
\hline chalcopyrite & & & \\
\hline pyrite & & & \\
\hline malachite & & & \\
\hline azurite & & & \\
\hline
\end{tabular}

Fig. 3. Simplified paragenetic sequence of mineral associations in the Farsesh deposit

tion, and also all petrographical studies indicate that the Farsesh deposit is probably an epigenetic vein filling that formed along faults and thrust shear zones in the dolomitic host rocks.

\section{Methodology}

Sampling was carried out in the winter of 2011. More than 50 samples were collected from the Farsesh deposit; they were selected based on the type of mineralisation. After fieldwork, 20 samples were selected for petrographical, geochemical and fluid-inclusion microthermometrical studies. The petrographic studies, using thin and polished sections, were performed in the microscopy laboratory of Shahid Chamran University. The fluid-inclusion microthermometric studies were carried out on double polished wafers using standard techniques. The parameters that were measured included the last ice-melting temperature $\left(\mathrm{T}_{\mathrm{LM}}\right)$ and the homogenisation temperature $\left(\mathrm{T}_{\mathrm{H}}\right)$ (Table 1$)$. The measurements were performed on a Linkam THMS 600 combined heating/freezing stage at the Isfahan University. This device can measure temperatures ranging from $-200^{\circ} \mathrm{C}$ to $+600^{\circ} \mathrm{C}$.

Concentrations of major, trace and rare earth elements in the samples were determined by inductively coupled plasma mass spectrometry in the ACME Analytical laboratories Ltd. in Vancouver, Canada. The precisions of the ACME Lab's $4 \mathrm{~A}$ (ICP-MS) and 4B analytical routines for major and 
Table 1. Microthermometric data of fluid inclusions in samples from the Farsesh barite deposit

\begin{tabular}{|c|c|c|c|c|c|c|c|c|}
\hline $\begin{array}{c}\text { Sample } \\
\text { no. }\end{array}$ & Texture & $\begin{array}{l}\text { Homog- } \\
\text { enisation } \\
\text { types }\end{array}$ & $\begin{array}{l}\text { Fluid-in- } \\
\text { clusion } \\
\text { types }\end{array}$ & Frequency & $\begin{array}{l}\text { Size } \\
(\mu \mathrm{m})\end{array}$ & $\operatorname{TLM}\left({ }^{\circ} \mathrm{C}\right)$ & $\mathrm{TH}\left({ }^{\circ} \mathrm{C}\right)$ & Salinity \\
\hline FC10 & massive & $L+V L$ & $\mathrm{P}$ & 1 & 7 & -7.5 & 180 & 15.8 \\
\hline FC10 & massive & $\mathrm{L}+\mathrm{VL}$ & $\mathrm{P}$ & 2 & 6 & -11.5 & 188 & 14.2 \\
\hline FC10 & massive & $L+V L$ & PS & 1 & 5 & -10.0 & 171 & 13.0 \\
\hline FC10 & massive & $\mathrm{L}+\mathrm{VL}$ & $\mathrm{P}$ & 2 & 5 & -10.0 & 125 & 16.1 \\
\hline FC10 & massive & $L+V L$ & $\mathrm{P}$ & 1 & 7 & -7.0 & 178 & 10.1 \\
\hline FA2 & massive & $\mathrm{L}+\mathrm{VL}$ & PS & 3 & 7 & -17.0 & 174 & 17.2 \\
\hline FA2 & massive & $L+V L$ & $\mathrm{P}$ & 2 & 5 & -10.0 & 167 & 13.3 \\
\hline FA2 & massive & $\mathrm{L}+\mathrm{VL}$ & $\mathrm{P}$ & 1 & 5 & -2.5 & 134 & 4.2 \\
\hline FA2 & massive & $\mathrm{L}+\mathrm{VL}$ & PS & 1 & 7 & -19.0 & 198 & 22.0 \\
\hline FA2 & massive & $\mathrm{L}+\mathrm{VL}$ & $\mathrm{P}$ & 3 & 5 & -2.3 & 130 & 4.3 \\
\hline FA2 & massive & $\mathrm{L}+\mathrm{VL}$ & $\mathrm{P}$ & 2 & 5 & -12.0 & 165 & 14.9 \\
\hline FB2 & vein & $\mathrm{L}+\mathrm{VL}$ & $\mathrm{P}$ & 2 & 8 & -14.0 & 125 & 16.1 \\
\hline FB2 & vein & $\mathrm{L}+\mathrm{VL}$ & $\mathrm{P}$ & 3 & 8 & -14.5 & 142 & 16.4 \\
\hline FB2 & vein & $\mathrm{L}+\mathrm{VL}$ & $\mathrm{P}$ & 2 & 8 & -19.5 & 167 & 17.5 \\
\hline FB2 & vein & $\mathrm{L}+\mathrm{VL}$ & $\mathrm{P}$ & 1 & 8 & -12.0 & 160 & 14.9 \\
\hline FB2 & vein & $\mathrm{L}+\mathrm{VL}$ & PS & 3 & 8 & -2.8 & 135 & 4.9 \\
\hline FB2 & vein & $\mathrm{L}+\mathrm{VL}$ & $\mathrm{P}$ & 2 & 8 & -8.5 & 163 & 11.9 \\
\hline FB3 & replacement & $\mathrm{L}+\mathrm{VL}$ & PS & 2 & 8 & -9.8 & 171 & 13.1 \\
\hline FB3 & replacement & $\mathrm{L}+\mathrm{VL}$ & PS & 2 & 8 & -18.5 & 191 & 17.4 \\
\hline FB3 & replacement & $\mathrm{L}+\mathrm{VL}$ & PS & 2 & 10 & -9.5 & 174 & 12.9 \\
\hline FB3 & replacement & $\mathrm{L}+\mathrm{VL}$ & $\mathrm{P}$ & 1 & 5 & -18.9 & 200 & 17.8 \\
\hline FB3 & replacement & $\mathrm{L}+\mathrm{VL}$ & $\mathrm{P}$ & 3 & 5 & -8.5 & 175 & 11.9 \\
\hline
\end{tabular}

rare earth element analysis, respectively, and the 1DX analytical routine for trace-element analysis were guaranteed with an accuracy and precision as may be expected for research-quality analyses (see http:/ / acmelab.com/services/). The detection limits of the ACME Lab's analytical routines used are $0.01-0.04 \%$ for major elements, $0.01-8$ ppm for trace elements and 0.01-0.1 ppm for rare earth elements (Table 2).

\section{Petrography and microthermometry of fluid inclusions}

Fluid-inclusion studies of four selected barite samples with vein, massive and replacement mineralisation indicated that small fluid inclusions $(<1 \mathrm{~m})$ are prevalent in the barite samples (Fig. 4 and Table 1). Because fluid inclusions in barite are susceptible to stretching during heating (Ulrich \& Bodnar, 1988), the microthermometric study was conducted on carefully selected large fluid inclusions with no evidence of necking-down or leakage, and trapped only in barite crystals. In addition, only values of $\mathrm{T}_{\mathrm{H}}$ measured in the first run were considered representative. Moreover, the low-temperature nature of barite mineralisation required that $\mathrm{T}_{\mathrm{H}}$ were determined before freezing individual fluid inclusions to avoid freeze stretching (Kelly et al., 2004).

According to the genetic classification of Shepherd et al. (1985), most of the fluid-inclusion types in barite samples from the Farsesh deposit were primary (P) and pseudosecondary (PS); according to their composition, these fluid inclusions are twophase inclusions, with liquid and vapour $(\mathrm{L}+\mathrm{V})(\mathrm{Ta}-$ 
Table 2. Concentrations of major oxides (in \%), and of trace and rare earth element (in ppm) in samples from the Farsesh barite and host rocks. ND = not detected

\begin{tabular}{|c|c|c|c|c|c|c|c|c|c|}
\hline Texture & $\begin{array}{l}\text { Host } \\
\text { rock }\end{array}$ & $\begin{array}{l}\text { Sulphide- } \\
\text { bearing } \\
\text { host rock }\end{array}$ & $\begin{array}{l}\text { Replace- } \\
\text { ment }\end{array}$ & Vein & Vein & Vein & Vein & Massive & Massive \\
\hline sample no. & HR1 & FB7 & FA5 & FA2 & FA4-1 & FA4-2 & FB2 & FB5 & FC3 \\
\hline \multicolumn{10}{|c|}{ major oxides (wt.\%) } \\
\hline $\mathrm{SiO} 2$ & 52.42 & 1.63 & 0.18 & 0.19 & 0.04 & 0.01 & 0.05 & 0.02 & 0.08 \\
\hline $\mathrm{A} 12 \mathrm{O} 3$ & 0.44 & 0.05 & 0.03 & 0.02 & ND & ND & ND & 0.02 & 0.02 \\
\hline $\mathrm{Fe} 2 \mathrm{O} 3$ & 3.2 & 35.61 & 0.07 & 0.14 & 0.43 & 0.08 & 0.35 & ND & 0.12 \\
\hline $\mathrm{MgO}$ & 5.2 & 0.08 & ND & 0.32 & 0.22 & 0.05 & 0.27 & ND & ND \\
\hline $\mathrm{CaO}$ & 17.52 & 0.23 & 0.45 & 54.65 & 53.89 & 11.08 & 55.04 & 0.09 & 0.04 \\
\hline $\mathrm{TiO} 2$ & 0.03 & ND & ND & ND & ND & ND & ND & ND & ND \\
\hline $\mathrm{MnO}$ & 0.47 & 0.05 & ND & 0.16 & 0.12 & 0.03 & 0.14 & ND & ND \\
\hline \multicolumn{10}{|c|}{ trace elements (ppm) } \\
\hline $\mathrm{Cu}$ & 74.9 & 10000.0 & 9.2 & 6.6 & 31 & 11.7 & 8.7 & 21.7 & 29.4 \\
\hline $\mathrm{Pb}$ & 4.9 & 604.6 & 0.6 & 2.2 & 6.5 & 1.6 & 2.1 & 0.8 & 1 \\
\hline $\mathrm{Zn}$ & 15 & 1013 & 2 & 3 & 11 & 3 & 3 & 5 & 2 \\
\hline $\mathrm{Sb}$ & 2.1 & 2000.0 & 0.1 & 0.1 & 0.5 & 0.3 & 0.2 & 0.6 & 0.7 \\
\hline $\mathrm{Hg}$ & 0.38 & 100.00 & 0.01 & 0.02 & 0.17 & 0.13 & 0.02 & 0.11 & 0.06 \\
\hline $\mathrm{Ba}$ & 8388 & 1299 & 50000 & 20079 & 39294 & 50000 & 2182 & 50000 & 50000 \\
\hline $\mathrm{Au}$ & 1.4 & 53.8 & 1.9 & 1.2 & 1.8 & 1.2 & 1.5 & 1 & 1.4 \\
\hline $\mathrm{Ga}$ & 1.4 & 2.7 & 3.5 & 10 & 6.9 & 4.6 & 1 & 3.7 & 2.2 \\
\hline $\mathrm{Sr}$ & 353.4 & 118 & 15162.6 & 1794 & 1637.6 & 2629.1 & 1471.7 & 10099.7 & 8823.6 \\
\hline $\mathrm{Y}$ & 1 & 0.6 & 1.7 & 8.9 & 7.7 & 2.9 & 1.9 & 1.3 & 1.5 \\
\hline \multicolumn{10}{|c|}{ rare earth elements (ppm) } \\
\hline $\mathrm{La}$ & 0.6 & 3.2 & 1.2 & 1.1 & 0.5 & 1.3 & 0.8 & 1.3 & 1.2 \\
\hline $\mathrm{Ce}$ & 0.8 & 0.8 & ND & 0.8 & 0.1 & 0.1 & 1.1 & ND & ND \\
\hline $\operatorname{Pr}$ & 0.1 & 0.02 & ND & 0.1 & ND & ND & 0.15 & ND & ND \\
\hline $\mathrm{Nd}$ & 0.5 & 0.5 & ND & 0.7 & 0.4 & 0.4 & 0.7 & ND & ND \\
\hline Sm & 0.14 & ND & ND & 0.94 & 0.36 & 0.16 & 0.15 & ND & ND \\
\hline $\mathrm{Eu}$ & 0.09 & 0.04 & 2.07 & 0.81 & 1.3 & 2.07 & 0.23 & ND & 2.12 \\
\hline $\mathrm{Gd}$ & 0.15 & 0.05 & 1.64 & 1.74 & 1.4 & 1.98 & 0.24 & 2.06 & 1.75 \\
\hline $\mathrm{Tb}$ & 0.03 & ND & 0.02 & 0.24 & 0.21 & 0.06 & 0.05 & 0.02 & 0.01 \\
\hline Dy & 0.12 & 0.09 & ND & 1.57 & 1.06 & 0.3 & 0.27 & ND & ND \\
\hline Ho & 0.05 & ND & 0.15 & 0.24 & 0.23 & 0.2 & 0.06 & 0.19 & 0.14 \\
\hline Er & 0.1 & ND & 0.18 & 0.43 & 0.37 & 0.34 & 0.1 & 0.24 & 0.15 \\
\hline $\mathrm{Tm}$ & 0.01 & ND & 0.01 & 0.06 & 0.05 & 0.03 & 0.03 & 0.01 & ND \\
\hline $\mathrm{Yb}$ & ND & ND & ND & 0.18 & 0.31 & 0.1 & 0.1 & 0.14 & 0.05 \\
\hline $\mathrm{Lu}$ & 0.01 & ND & ND & 0.04 & 0.02 & 0.01 & 0.02 & ND & ND \\
\hline$\Sigma$ REE & 2.7 & 4.7 & 5.27 & 8.95 & 6.31 & 7.49 & 4 & 3.96 & 5.42 \\
\hline $\mathrm{Ce} / \mathrm{La}$ & 1.3 & 0.25 & - & 0.72 & 0.2 & 0.07 & 1.3 & - & - \\
\hline Y/Ho & 20 & 0 & 11.33 & 37.08 & 33.47 & 14.5 & 31.66 & 6.8 & 10.71 \\
\hline$(\mathrm{La} / \mathrm{Lu}) \mathrm{CN}$ & 62.5 & 0 & - & 29 & 2.5 & 135 & 41.25 & - & - \\
\hline$\left(\mathrm{Eu} / \mathrm{Eu}^{*}\right) \mathrm{CN}$ & 1.8 & 0 & - & 1.93 & 5.63 & 11.54 & 3.7 & - & - \\
\hline$\left(\mathrm{La} / \mathrm{La}^{*}\right) \mathrm{CN}$ & 2.42 & 1.58 & - & 0.74 & 1.2 & 1.6 & 1.8 & - & - \\
\hline$\left(\mathrm{Gd} / \mathrm{Gd}^{*}\right) \mathrm{CN}$ & 0.86 & 0 & 22.36 & 1.32 & 1.49 & 6.76 & 0.95 & 27.88 & 48.09 \\
\hline$\left(\mathrm{Ce} / \mathrm{Ce}^{*}\right) \mathrm{SN}$ & 0.7 & 0.01 & - & 0.5 & 0.002 & 0.002 & 0.7 & - & - \\
\hline$(\mathrm{Ce} / \mathrm{Yb}) \mathrm{CN}$ & 0 & - & - & 1.18 & 0.08 & 0.25 & 2.7 & - & - \\
\hline$(\mathrm{Ce} / \mathrm{Sm}) \mathrm{CN}$ & 1.3 & - & - & 0.2 & 0.06 & 0.14 & 1.6 & - & - \\
\hline$(\mathrm{La} / \mathrm{Yb}) \mathrm{CN}$ & - & - & - & 4.11 & 0.78 & 8.91 & 5.48 & 6.34 & 16.82 \\
\hline$(\mathrm{La} / \mathrm{Ce}) \mathrm{CN}$ & 8.3 & 1.5 & - & 2.8 & 10.83 & 27.2 & 1.53 & - & - \\
\hline
\end{tabular}


Fig. 4. Types of fluid inclusions within barite crystals

A: Two-phase vapour, liquid-rich and some monophase (liquid phase) fluid inclusions; B: Twophase (liquid/vapour) inclusions within barite crystals
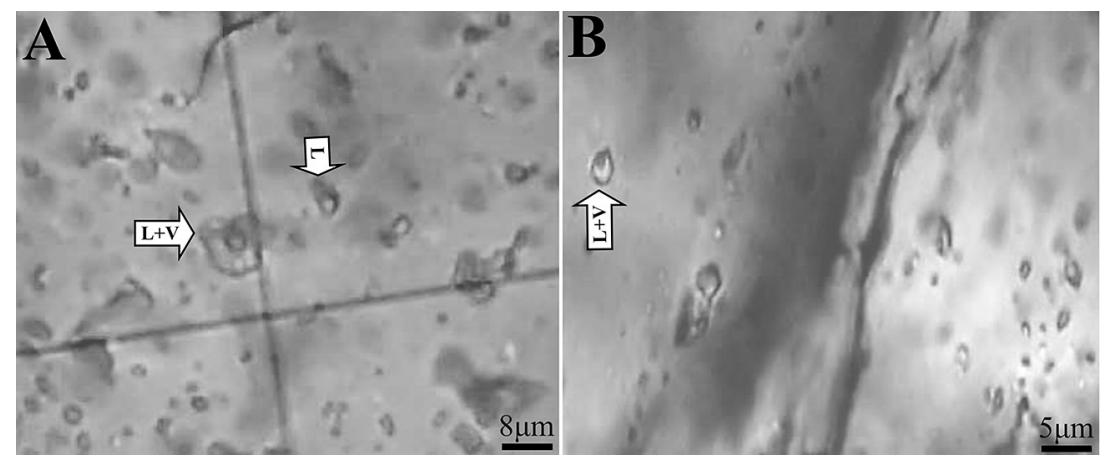

ble 1 and Fig. 4) (Shepherd et al., 1985). Single-phase inclusions (only liquid) are rare. Unfortunately, microthermometric analysis of these fluid inclusions was not feasible because of their small size and the turbidity of the inclusions. The microthermometric data were measured from two-phase $(\mathrm{L}+\mathrm{V})$ fluid inclusions. Most of the studied fluid inclusions changed to liquid phases during the heating experiment and got homogeneous. It can therefore be concluded that the Farsesh barite deposit formed under hydrothermal conditions from hydrothermal fluids (Shepherd et al., 1985).

The values of $T_{H}$ measured from more than 30 fluid inclusions in the barite range from $125^{\circ} \mathrm{C}$ to $200^{\circ} \mathrm{C}$ with peaks at $160^{\circ} \mathrm{C}$ and $180^{\circ} \mathrm{C}$ (Fig. $5 \mathrm{~A}$ ), with an average of $166^{\circ} \mathrm{C}$. During the measurements of $\mathrm{T}_{\mathrm{H}^{\prime}}$ vapour $(\mathrm{L}+\mathrm{V})$ inclusions became homogenised in the liquid phase (Table 1). No correlation was found between the sizes of the fluid inclusions and the $T_{H}$ values, indicating that the fluid inclusions did not stretch due to over-heating and that the measured $\mathrm{T}_{\mathrm{H}}$ values are good estimates of the mineralisation temperatures. The values of $\mathrm{T}_{\mathrm{LM}}$ varied from $-19.5^{\circ} \mathrm{C}$ to $-2.5^{\circ} \mathrm{C}$ (Table 1 ), with an average of $-10.9^{\circ} \mathrm{C}$. The salinity of the fluids (in $\mathrm{wt} \% \mathrm{NaCl}$ eq.) was estimated from the $\mathrm{T}_{\mathrm{LM}}$ data using the equation of Bodnar \& Vityk (1994). The $\mathrm{T}_{\mathrm{LM}}$ data yield fluid salinities ranging from 4.2 to $20 \mathrm{wt} \% \mathrm{NaCl}$ eq. (Table 1 ; Fig. 5B), with an average of $13.2 \mathrm{wt} \% \mathrm{NaCl}$ eq.

The graph of the salinity versus the homogenisation temperature (Fig. 6) (Kesler, 2005) of the fluid inclusions shows the highest concentration of fluid inclusions in hydrothermal-type water, but the presence of low-salinity fluids - especially with $<5$ $\mathrm{NaCl}$ wt\% (basinal water has $5-22 \mathrm{NaCl}$ wt\%) (Bodnar, 1999) - indicate the participation of meteoritic water in the mineralisation process (cf. Kelley et al., 2004). According to the homogenisation temperature, basinal water contributed most to the mineralisation process. Based on the microthermometric data of the fluid inclusions, the Farsesh barite deposit was formed from hydrothermal type basinal water (Fig. 6) (Kesler, 2005) with low to moderate salinity $\left(4-20 \mathrm{wt} \% \mathrm{NaCl}\right.$ eq.), low $\mathrm{T}_{\mathrm{LM}}\left(-20^{\circ} \mathrm{C}\right.$ to $\left.-2^{\circ} \mathrm{C}\right)$ and low to moderate $\mathrm{T}_{\mathrm{H}}\left(125-200^{\circ} \mathrm{C}\right)$.

\section{Geochemistry}

Geochemical analysis of the trace and rare earth elements (REE) is a powerful instrument for hydrothermal mineralisation studies, and is used in order to recognise the formation and to detect the source of mineralised fluids in different geological environments (see, among others, Guichard et al., 1979; Jewell \& Stallard, 1991; Bozkaya \& Gökce, 2004; Clark et al., 2004; Jurkovic et al., 2010; Noguchi et al., 2011). Barite minerals can be formed in both marine and terrestrial environments and can be used as a valuable system in REE studies (Guichard et al., 1979). Geochemical indicators of barite mineralisation can be obtained through the detection of

Fig. 5. Frequency distribution of parameters for fluid inclusions hosted in barite samples of the Farsesh deposit

A: Homogenization temperature $\left(\mathrm{T}_{\mathrm{H}}\right)$; $\mathbf{B}$ : Salinity (equiv. wt. \% $\mathrm{NaCl}$ ).

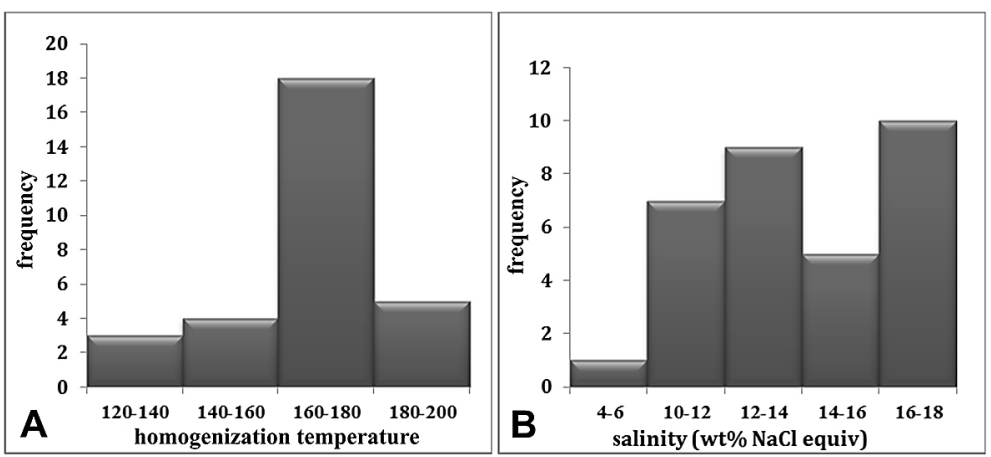




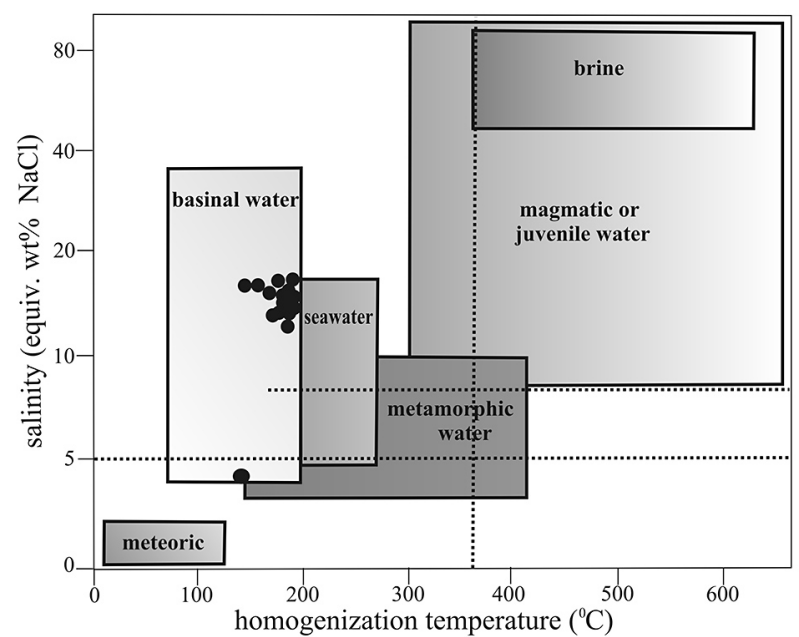

Fig. 6. Detection of the mineralizsd fluid in the Farsesh deposit using the salinity vs. homogeneous temperature histogram (after Kesler, 2005)

sedimentary host-rock chemistry, as this may help to reconstruct the physio-chemical conditions during precipitation.

\subsection{Major elements}

The barite samples have very low contents of $\mathrm{SiO}_{2}$ $(0.01-0.19 \%), \mathrm{Al}_{2} \mathrm{O}_{3}(<0.01-0.03 \%), \mathrm{Fe}_{2} \mathrm{O}_{3}(<0.04-$ $0.43 \%), \mathrm{MnO}(<0.01-0.16 \%)$ (only in samples of vein barite) and $\mathrm{MgO}(<0.01-0.32 \%$ ) (only in samples of vein barite), whereas samples of the host rocks have higher contents of $\mathrm{SiO}_{2}(1.63-52.42 \%), \mathrm{Al}_{2} \mathrm{O}_{3}$ (0.05-0.44\%), $\mathrm{Fe}_{2} \mathrm{O}_{3}(3.2-35.61 \%), \mathrm{MnO}(0.05-0.47 \%)$ and $(0.08-5.2 \%)$. The $\mathrm{CaO}$ content in the vein-barite samples range from $11.08-55.04 \%$; in the samples of massive and replacement barite, the $\mathrm{CaO}$ content is very low $(0.04-0.45 \%)$, whereas in host rocks it ranges from (0.23-17.52\%) (Table 2). The low content of $\mathrm{Al}_{2} \mathrm{O}_{3}$ and $\mathrm{TiO}_{2}$ in the Farsesh barite and host-rock samples points at hydrothermal generation of the ores, because in hydrothermal deposits, with low contents of Ti- and Al-containung detrital material, the hydrothermal elements are enriched (Lottermoser \& Ashley, 1996). Concentrations of $\mathrm{Al}$ and $\mathrm{Ti}$ in marine sediments are largely derived from weathered continental material, whereas Fe and $\mathrm{Mn}$ are derived from submarine hydrothermal vents (Jewell \& Stallard, 1991).

\subsection{Trace elements}

The barite samples have very low concentrations of most trace elements, compared to the host-rock samples (Table 2). Of the 28 elements identified in the barite samples, only nine were detected in all barite samples, whereas the other elements were lacking in at least one of the barite samples (Table 2). The $\mathrm{Ba}$ and $\mathrm{Sr}$ concentrations in the host-rock samples are consistently lower than in the nine barite samples, whereas the $\mathrm{Au}$ and $\mathrm{Ga}$ concentrations in the samples from the host rock and the barite are more or less similar (except for Au in one host-rock sample) (Fig. 7). In contrast, the concentrations of $\mathrm{Pb}, \mathrm{Zn}, \mathrm{Hg}$, $\mathrm{Cu}$ and $\mathrm{Sb}$ in the host-rock samples are one to three orders of magnitude higher than in the barite samples. This implies that Ba and Sr enrichment in the Farsesh barite deposit was accompanied by depletion of $\mathrm{Pb}, \mathrm{Zn}, \mathrm{Hg}, \mathrm{Cu}$ and $\mathrm{Sb}$.

The relatively high $\mathrm{Sr}$ concentrations and the presence of barite with $\mathrm{Sr}$ indicates an origin of the Farsesh barite deposit from a low-temperature hydrothermal solution (e.g., Kato \& Nakamura, 2003; Jurkovic et al., 2010). The host-rock samples are depleted in Ba compared to the barite samples (Fig. 7). This suggests, in combination with the difference in $\mathrm{SiO}_{2}$ contents of the barite and host-rock samples, that the barite mineralisation in open spaces was accompanied by silicification in the limestone host rocks.

\subsection{Rare earth elements}

The rare earth element (REE) concentrations of the Farsesh barite deposit (Table 2), normalised using the average chondrite abundances of McDonough \& Sun (1995), show an extremely low content of total REE ( $\mathrm{REE}$ ), varying from 3.96 to $8.95 \mathrm{ppm}$, with a mean of $5.911 \mathrm{ppm}$. The chondrite-normalized pattern of the barite samples shows an LREE enrichment, as opposed to the HREE $\left(\mathrm{La}_{\mathrm{CN}} / \mathrm{Lu}_{\mathrm{CN}}>1\right)$ (Table 2; Fig. 8A) and slightly positive (La/La*) $=0.74-1.8$ and $\left(\mathrm{Gd} / \mathrm{Gd}^{*}\right)_{\mathrm{CN}}=0.95-27.88$ anomalies (Table 2) of the Farsesh barite samples deposited in the marine environment (cf. Chen et al., 2006; Alexander et al., 2008). The REE pattern of the Farsesh barite samples exhibit a positive Eu anomaly ranging from $\left(\mathrm{Eu} / \mathrm{Eu}^{*}\right)_{\mathrm{CN}}=1.93$ to 11.54 (Table 2), suggesting that these samples were deposited from exhalative hydrothermal fluids (cf. Barret et al., 1990), in a relatively reducing environment (cf. Guichard et al., 1979). The negative $\left(\mathrm{Ce} / \mathrm{Ce}^{*}\right)_{\mathrm{SN}}$ anomalies (0.002-0.7), with an average of 0.21 , indicate that the Farsesh barite samples deposited from seawater in the marine sediments were formed far away from terrigenous sources (Murray et al., 1990; Murray, 1994). According to Guichard et al. (1979), the Ce/ La ratios indicate a marine $(\mathrm{Ce} / \mathrm{La}<1)$ or terrestrial genesis $(\mathrm{Ce} / \mathrm{La}>1)$ for the barite samples.The $\mathrm{Ce} /$ 
Fig. 7. Trace-element concentrations in samples of barite and host rocks (see Table 2), normalised against the corresponding global average trace-element concentrations in limestones (Levinson, 1974). The global average Ga concentration is from Burton et al. (1959). The normalised trace-element data are jointed by thin dotted lines to clarify the barite/host rock trend, but do not depict a continuous trend from one sample to another

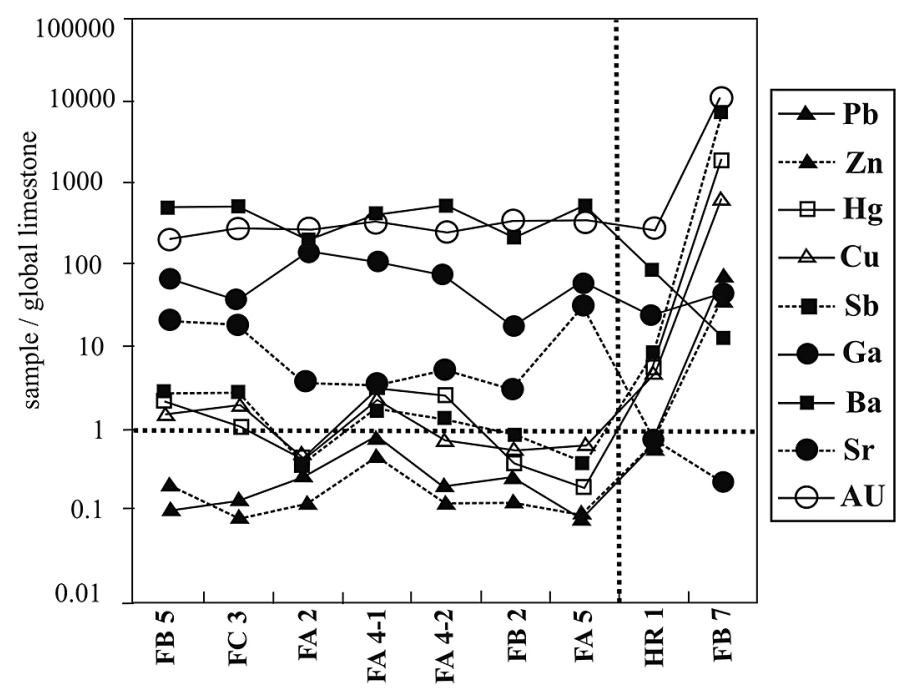

La ratios in the Farsesh barite samples, which range from 0.07 to 1.3 with an average of 0.57 (Table 2), are similar to marine barite.

The REE patterns of the host rock samples (HR-1 and FB-7) (Fig. 8B) show a significantly lower REE content (2.7 and $4.7 \mathrm{ppm}$ ) than the Farsesh barite samples (Fig. 8A), and a slightly more positive $\mathrm{Eu}$ anomaly (1.8) than the barite samples. The negative Ce anomaly (0.7-0.01) of the host rocks indicates that the host-rock samples precipitated in an oxygenated open-marine environment, at a considerable distance from terrigenous sources (cf. Chen et al., 2006).

\section{Comparison of the Farsesh barite deposit with other barite occurrences}

To determine the probable origin of the Frasesh Barite deposit, the profiles of average REE values (normalised using McDonough \& Sun, 1995) of the Farsesh barite samples were compared with those of other barite deposits in various environments (Fig. 9A), namely (a) Bijgan in Iran (Ehya, 2012), (b) Karalar in Turkey (Bozkaya \& Gökce, 2004; Gökce \& Bozkaya, 2008), (c) Mt.Mulga in Australia (Griessmann et al., 2010), (e) Bouznika in Morocco (Jébrak et al., 2011), (f) Duboki Vagan in Bosnia (Jurković et al., 2011), and in the southern California continental borderland (SCCB) (Hein et al., 2007). The geology, environment, tectonic setting and genesis of these deposits are summarised in Table 3.

It appears that the age of the host rocks of the Frasesh barite deposit is similar to that of the Karalar (Bozkaya \& Gökce, 2004), the Mt. Mulga (Griessmann et al., 2010) and the Duboki Vagan (Jurković et al., 2011) barite deposits, that all have Pal-

aeozoic host rocks. Vein-type barite mineralisation occurs along fault zones in strongly deformed host rocks in the Farsesh, the Karalar and the Duboki Vagan barite deposits.

A comparison of the REE-average patterns of the above-mentioned deposits with the REE-average of the Farsesh barite deposits indicates that in all barite
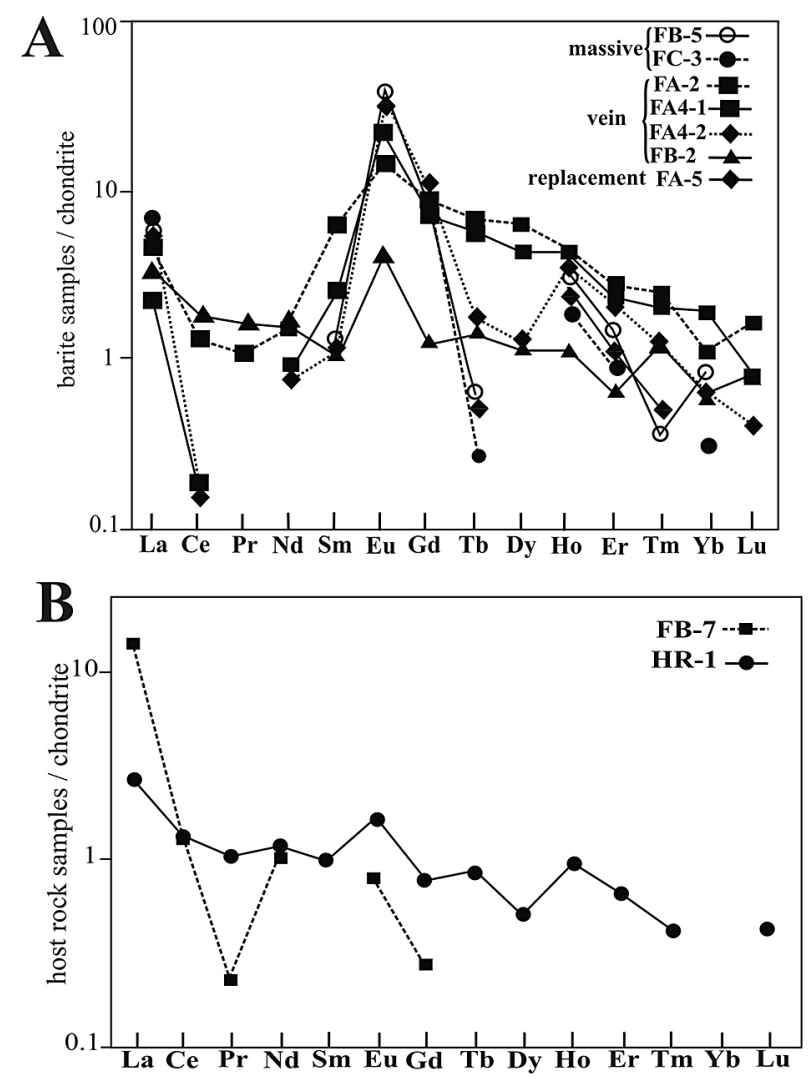

FFig. 8. Chondrite-normalised REE patterns. The chondrite data for normalisation are from McDonough \& Sun (1995)

A: Barite samples; B: Host-rock samples. 
deposits, including the Farsesh barite deposit (Fig. 9A), the REE patterns are present in very low concentrations (Table 4). The $\mathrm{La}_{\mathrm{CN}} / \mathrm{Lu}_{\mathrm{CN}}$ ratios of these deposits are $>1$, indicating LREE enrichment. The chondrite-normalised REE patterns of these barite deposits are characterised by a slightly negative $\mathrm{Ce}$ anomaly and by positive La and Gd anomalies that are commonly considered as features of barite deposited from seawater in marine sediments (Murray et al., 1990; Alexander et al., 2008). The positive Eu anomalies and REE patterns of these barite deposits point at an exhalative hydrothermal origin (Barret et al., 1990). The low Ce/La ratios of the barites from the Bijgan (Ehya, 2012), Bouznika (Jébrak et al., 2011) and Duboki Vagan (Jurković et al., 2011) deposits show that these deposits are marine $(\mathrm{Ce} / \mathrm{La}<1)$, similar to the Farsesh deposit, whereas the high $\mathrm{Ce} / \mathrm{La}$ ratios of barite from the Mt.Mulga (Griessmann et al., 2010), SCCB (Hein et al., 2007) and Karalar (Bozkaya \& Gökce, 2004; Gökce \& Bozkaya, 2008) deposits indicate that these barite deposits are terrestrial (Ce/La>1) (Guichard et al., 1979).

Comparizon of the REE patterns of the Frasesh barite samples with the SCCB barite deposit (Hein

Table 3. Geological characteristics of the Farsesh barite deposit and other important barite deposits elsewhere

\begin{tabular}{|c|c|c|c|c|c|c|c|}
\hline $\begin{array}{c}\text { Barite } \\
\text { deposits }\end{array}$ & Bouznika $^{1}$ & Mt. Mulga ${ }^{2}$ & $\mathrm{SCCB}^{3}$ & Bijgan $^{4}$ & Karalar $^{5}$ & $\begin{array}{l}\text { Duboki } \\
\text { Vagan }^{6}\end{array}$ & Farsesh $^{7}$ \\
\hline 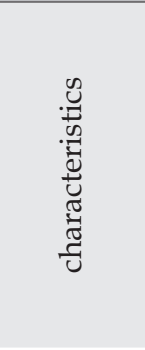 & $\begin{array}{l}\text { stockwork } \\
\text { and strati- } \\
\text { form lenses } \\
\text { within felsic } \\
\text { tuffs }\end{array}$ & $\begin{array}{l}\text { stratiform } \\
\text { barite } \\
\text { contains Fe } \\
\text { oxides, } \\
\text { Cu-Au min- } \\
\text { eralisation }\end{array}$ & $\begin{array}{l}\text { friable, } \\
\text { highly po- } \\
\text { rous active- } \\
\text { ly growing } \\
\text { seafloor } \\
\text { mounds } \\
\text { to dense, } \\
\text { brecciated } \\
\text { veins }\end{array}$ & $\begin{array}{l}\text { lenticular } \\
\text { ore body } \\
\text { with calcite, } \\
\text { Fe oxides } \\
\text { and clay } \\
\text { materials }\end{array}$ & $\begin{array}{l}\text { veins along } \\
\text { fault zones } \\
\text { of strongly } \\
\text { deformed } \\
\text { host rocks }\end{array}$ & $\begin{array}{l}\text { veins with } \\
10 \% \mathrm{~Pb}- \\
\mathrm{Zn}-\mathrm{Fe}-\mathrm{Cu} \\
\text { sulphides }\end{array}$ & $\begin{array}{l}\text { veins with } \\
\text { quartz and } \\
\text { opaque } \\
\text { minerals }\end{array}$ \\
\hline 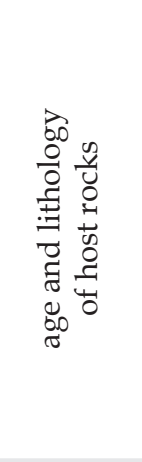 & $\begin{array}{l}\text { Cambrian } \\
\text { terranes } \\
\text { and vol- } \\
\text { cano-sed- } \\
\text { imentary } \\
\text { facies on the } \\
\text { north-west- } \\
\text { ern flank of } \\
\text { the Oued } \\
\text { Rhebar } \\
\text { andesite } \\
\text { volcanics }\end{array}$ & $\begin{array}{l}\text { meta-sed- } \\
\text { imentary } \\
\text { rocks in } \\
\text { the lower } \\
\text { part of the } \\
\text { Willyamaz } \\
\text { Supergroup } \\
\text { (Palaeo-pro- } \\
\text { terozoic) }\end{array}$ & $\begin{array}{l}\text { Mesozoic, } \\
\text { Cenozoic } \\
\text { basement, } \\
\text { Quaternary, } \\
\text { continental } \\
\text { crust and } \\
\text { Neogene } \\
\text { volcanism }\end{array}$ & $\begin{array}{l}\text { uppermost } \\
\text { part of } \\
\text { Eocene vol- } \\
\text { cano-sed- } \\
\text { imentary } \\
\text { rocks }\end{array}$ & $\begin{array}{l}\text { Late Cam- } \\
\text { brian to Late } \\
\text { Cretaceous } \\
\text { detrital } \\
\text { rocks, } \\
\text { Permian } \\
\text { limestones } \\
\text { and Triassic } \\
\text { sediments. }\end{array}$ & $\begin{array}{l}\text { Early Palae- } \\
\text { ozoic } \\
\text { metaclastics } \\
\text { and Triassic } \\
\text { dolomites }\end{array}$ & $\begin{array}{l}\text { Permian } \\
\text { dolomitic } \\
\text { limestone }\end{array}$ \\
\hline 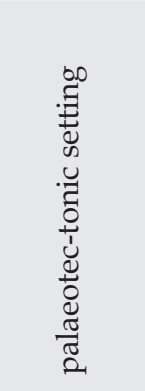 & $\begin{array}{l}\text { opening of } \\
\text { an Early } \\
\text { Palaeozoic } \\
\text { rift on the } \\
\text { NW margin } \\
\text { of Gond- } \\
\text { wana }\end{array}$ & $\begin{array}{l}\text { Olary Do- } \\
\text { main in the } \\
\text { S-W part of } \\
\text { the Protero- } \\
\text { zoic } \\
\text { Curnamona } \\
\text { Craton }\end{array}$ & $\begin{array}{l}\text { continental } \\
\text {-margin } \\
\text { of the broad } \\
\text { San Andreas }\end{array}$ & $\begin{array}{l}\text { Urumieh- } \\
\text { Dokhtar } \\
\text { volcanic } \\
\text { subzone of } \\
\text { the Zagros } \\
\text { Folded Belt }\end{array}$ & $\begin{array}{l}\text { Alanya } \\
\text { tectonic } \\
\text { window in } \\
\text { the central } \\
\text { Taurides }\end{array}$ & $\begin{array}{l}\text { Palaeozoic } \\
\text { complex } \\
\text { of SEB and } \\
\text { MSBN }\end{array}$ & $\begin{array}{l}\text { Sanandaj-S } \\
\text { irjan Zone } \\
\text { of the } \\
\text { Zagros } \\
\text { Fold Belt. }\end{array}$ \\
\hline 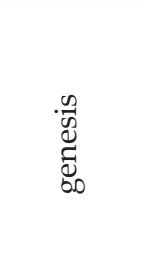 & $\begin{array}{l}\text { K- and } \\
\text { Ba-rich hy- } \\
\text { drothermal } \\
\text { fluids mixed } \\
\text { with sul- } \\
\text { phates from } \\
\text { seawater }\end{array}$ & SEDEX style & $\begin{array}{l}\text { deep-seated } \\
\text { hydrother- } \\
\text { mal fluids } \\
\text { mixed with } \\
\text { seawater }\end{array}$ & $\begin{array}{l}\text { active } \\
\text { submarine } \\
\text { hydro-ther- } \\
\text { mal fluid }\end{array}$ & $\begin{array}{l}\text { mixture of } \\
\text { hydrother- } \\
\text { mal fluid } \\
\text { with seawa- } \\
\text { ter }\end{array}$ & $\begin{array}{l}\text { influence of } \\
\text { seawater on } \\
\text { epigenetic } \\
\text { hydro- } \\
\text { ther-mal } \\
\text { fluids }\end{array}$ & $\begin{array}{l}\text { seawa- } \\
\text { ter-derived } \\
\text { hydro- } \\
\text { ther-mal } \\
\text { fluid }\end{array}$ \\
\hline
\end{tabular}

References: ${ }^{1}$ Jébrak et al. (2011); ${ }^{2}$ Griessmann et al. (2010); ${ }^{3}$ Hein et al. (2007); ${ }^{4}$ Ehya (2011); ${ }^{5}$ Bozkaya and Gökce 2004, ${ }^{6}$ Jurković et al. (2010); ${ }^{7}$ this study. 

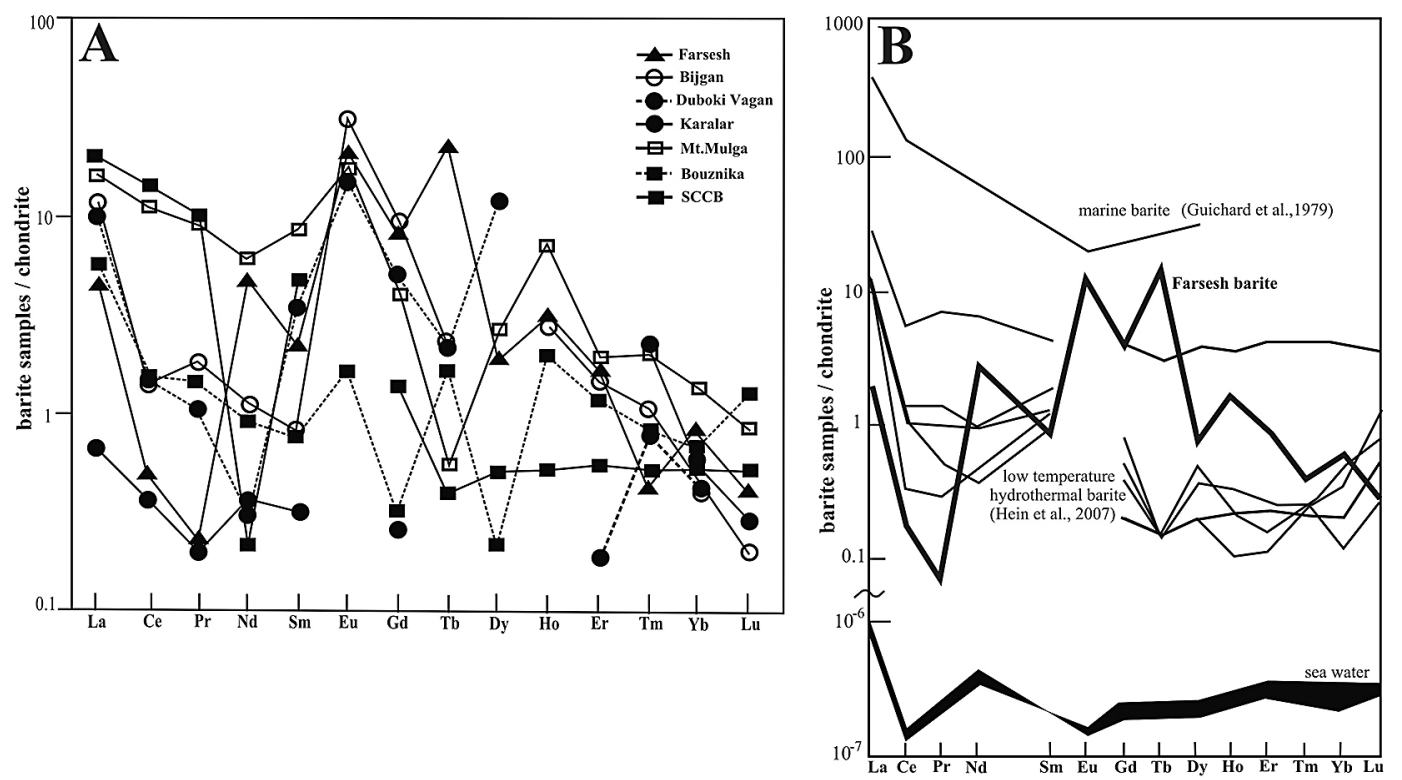

Fig. 9. Comparison of the rare earth element distributions of barite samples from the Farsesh area with other deposits A: Comparison with various barite deposits (references in Table 3). Chondrite data used for normalisation are from McDonough \& Sun (1995); B: Marine, low-temperature, hydrothermal barites compared with seawater (data from Guichard et al., 1979); Hein et al., 2007). After Griffith \& Paytan (2012)

et al., 2007) and seawater (Guichard et al., 1979) (Fig. 9B) indicates that that REE profiles of the Farsesh barite belong to the low-temperature hydrothermal barite deposits, similar to the SCCB, Bijgan, Duboki Vagan, Mt.Mulga and Bouznika barite deposits, and that they differ from the seawater and Karalar barite deposits (Fig. 9A). Therefore, the occurrence of hydrothermal barite in the Frasesh deposits points at low to intermediate temperatures $\left(150-250^{\circ} \mathrm{C}\right)$, at the sea bottom near hydrothermal plumes (Hein et al., 2007), where they were accompanied by minor amounts of base-metal sulphides (Torres et al., 2003). As shown in Figure 9B, there is a non-similarity between the REE distributions of the Farsesh barite deposit and the REE patterns of marine barite (Guichard et al., 1979).
Comparison of the distribution of normalised REE values of the barite deposits that were mentioned in the $\mathrm{Ce}_{\mathrm{N}} / \mathrm{Sm}_{\mathrm{N}}$ versus $\mathrm{Ce}_{\mathrm{N}} / \mathrm{Yb}_{\mathrm{N}}$ diagram (Table 4; Fig. 10) shows that the values of the Farsesh barite deposit are very close to those of seawater, and thus are similar to the vein-type Karalar barite deposits (Bozkaya \& Gökce, 2004; Gökce \& Bozkaya, 2008). The fact that the Farsesh barite deposit closely resembles seawater suggests that the barite mineralisation occurred from a seawater-derived hydrothermal fluid.

\section{Conclusions}

The Farsesh barite deposit is probably an epigenetic vein occurrence, with open-space filling veins;
Fig. 10. Plot of the Farsesh barite deposit and host-rock samples against similar barite occurrences in a $\mathrm{Ce}_{\mathrm{N}} / \mathrm{Sm}_{\mathrm{N}}$ versus $\mathrm{Ce}_{\mathrm{N}} / \mathrm{Yb}_{\mathrm{N}}$ diagram. Normalised using McDonough \& Sun (1995)

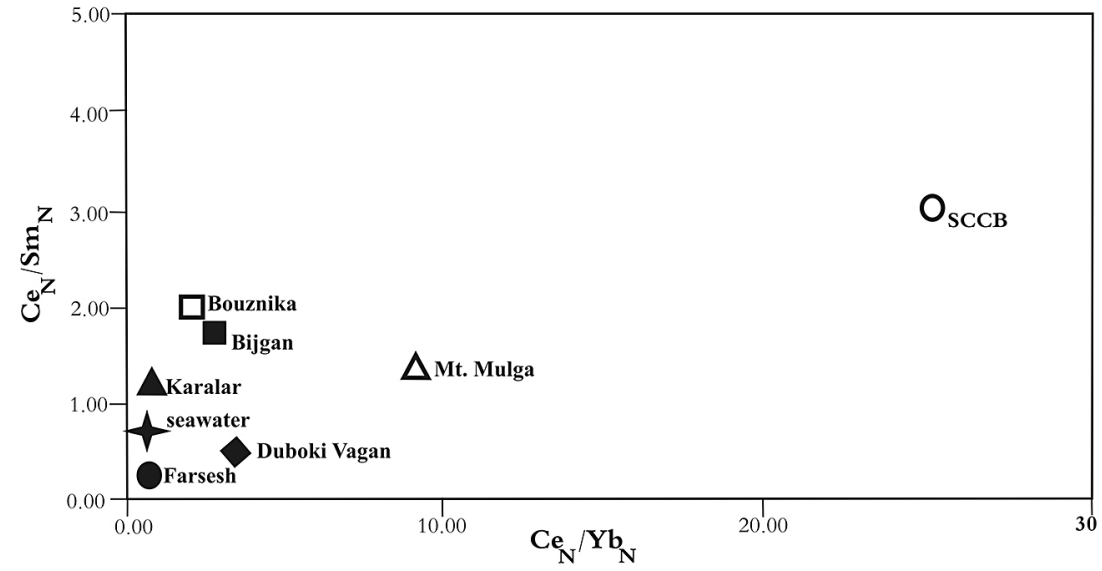


Table 4. Comparison of the average normalised REE contents of the Farsesh deposit with various other barite occurrences. The chondrite data used for normalisation are from McDonough \& Sun (1995). References to the barite deposits are given in Table 3

\begin{tabular}{|c|c|c|c|c|c|c|c|}
\hline REE & Bouznika $^{1}$ & Mt. Mulga ${ }^{2}$ & $\mathrm{SCCB}^{3}$ & Bijgan $^{4}$ & Karalar $^{5}$ & $\begin{array}{l}\text { Duboki } \\
\text { Vagan }^{6}\end{array}$ & Farsesh $^{7}$ \\
\hline $\mathrm{La}$ & 1.3 & 3.69 & 4.11 & 2.89 & 0.16 & 2.40 & 1.05 \\
\hline $\mathrm{Ce}$ & 0.9 & 7.26 & 8.13 & 0.89 & 0.23 & 0.90 & 0.30 \\
\hline $\operatorname{Pr}$ & 0.13 & 0.84 & 0.89 & 0.17 & 0.02 & 0.10 & 0.02 \\
\hline $\mathrm{Nd}$ & 0.40 & 2.72 & 0.11 & 0.52 & 0.17 & 0.15 & 2.20 \\
\hline $\mathrm{Sm}$ & 0.11 & 1.23 & 0.63 & 0.12 & 0.05 & 0.45 & 0.31 \\
\hline $\mathrm{Eu}$ & 0.09 & 0.90 & ND & 1.67 & ND & 0.85 & 1.22 \\
\hline Gd & 0.06 & 0.85 & 0.26 & 1.73 & 0.05 & 1.02 & 1.54 \\
\hline $\mathrm{Tb}$ & 0.06 & 0.02 & 0.01 & 0.078 & - & 0.08 & 0.80 \\
\hline Dy & 0.05 & 0.63 & 0.12 & - & - & 2.78 & 0.45 \\
\hline Ho & 0.11 & 0.37 & 0.03 & 0.15 & - & - & 0.17 \\
\hline Er & 0.19 & 0.30 & 0.09 & 0.23 & - & 0.03 & 0.25 \\
\hline $\mathrm{Tm}$ & 0.02 & 0.05 & 0.01 & 0.03 & 0.05 & 0.02 & 0.01 \\
\hline $\mathrm{Yb}$ & 0.11 & 0.21 & 0.08 & 0.09 & 0.08 & 0.07 & 0.13 \\
\hline $\mathrm{Lu}$ & 0.03 & 0.02 & 0.01 & 0.01 & 0.01 & - & 0.01 \\
\hline Y & 0.9 & 13.00 & 3.40 & 1.43 & 1.43 & - & 3.05 \\
\hline$\Sigma \mathrm{REE}$ & 3.56 & 17.17 & 14.48 & 9.02 & 0.81 & 5.27 & 8.45 \\
\hline $\mathrm{Ce} / \mathrm{La}$ & 0.69 & 1.96 & 1.97 & 0.30 & 1.43 & 0.37 & 0.28 \\
\hline $\mathrm{Y} / \mathrm{Ho}$ & 8.18 & 35.13 & 125.92 & 9.72 & - & - & 18.39 \\
\hline $\mathrm{LaN} / \mathrm{Lu} \mathrm{N}$ & 4.50 & 19.15 & 35.55 & 60 & 2.37 & - & 10.89 \\
\hline$\left(\mathrm{La} / \mathrm{La}^{*}\right) \mathrm{N}$ & 2.23 & 1.02 & 0.61 & 4.21 & 7.05 & 3.90 & 0.49 \\
\hline$\left(\mathrm{Gd} / \mathrm{Gd}^{*}\right) \mathrm{N}$ & 0.23 & 1.37 & 0.78 & 5.10 & 2.50 & 2.06 & 12.19 \\
\hline$\left(\mathrm{Ce} / \mathrm{Ce}^{*}\right) \mathrm{SN}$ & 0.47 & 0.95 & 0.17 & 0.23 & 0.88 & 0.30 & 0.21 \\
\hline$\left(\mathrm{Eu} / \mathrm{Eu}^{*}\right) \mathrm{N}$ & 3.70 & 2.54 & - & - & - & 10.58 & 2.73 \\
\hline $\mathrm{CeN} / \mathrm{SmN}$ & 1.97 & 1.42 & 3.11 & 1.79 & 1.20 & 0.48 & 0.23 \\
\hline $\mathrm{CeN} / \mathrm{YbN}$ & 2.14 & 9.07 & 25.42 & 2.70 & 0.72 & 3.37 & 0.63 \\
\hline
\end{tabular}

$\mathrm{ND}=$ not detected. In the SCCB and Bijgan deposits, Eu could not be determined because of interference by Ba. In the Karalar deposit, Eu is below the detection limit.

it occurs as massive and replacement ores along faults and fractures of the Permian dolomitic limestone host rock. Neither a geological nor a genetic relationship was found between the volcanics and the barite mineralisation in the Farsesh area. The Farsesh deposit has a simple mineralogical paragenesis with barite as the main mineral, with smaller amounts of calcite, quartz and opaque minerals (consisting of iron oxide, pyrite, chalcopyrite and covellite).

The geochemical characteristics of the main and trace elements, such as the low quantities of $\mathrm{Al}_{2} \mathrm{O}_{3}$ and $\mathrm{TiO}_{2}$ in the barite and the host rock and the high concentrations of $\mathrm{Ba}$ and $\mathrm{Sr}$ accompanied by depletion of $\mathrm{Cu}, \mathrm{Hg}, \mathrm{Zn}, \mathrm{Pb}, \mathrm{Sb}$ in the barite samples, indicate that the Farsesh barite mineralisation was probably due to low-temperature mineral-rich hydrothermal fluids. Comparison of the REE content of the barite with that of seawater and hydrothermal barite deposits, in combination with the posi- tive anomalies of Eu and the negative anomalies of $\mathrm{Ce}$, show that the Farsesh deposit is similar to hydrothermal deposits. The lack of economic sulphidic minerals in the Farsesh deposit suggests that the source was probably a low-temperature hydrothermal fluid. Petrographical and thermometry data of the barite samples show the presence of two phases $(\mathrm{L}+\mathrm{V})$ in the fluid inclusions and indicate a low to middle salinity of the hydrothermal basinal water.

Field studies, in combination with the mineralogy of the deposits and the geochemistry of the fluid inclusions, lead to the conclusion that the precipitation of barite as a result of mixing with seawater and of a decrease in the temperature of the hydrothermal fluids was responsible for the formation of the barite occurrence in the Permain carbonates. The emplacement of andesitic volcanic rocks is considered not to have been important for the barite mineralisation in the study area. 


\section{References}

Alavi, M., 1994. Tectonics of the Zagros orogenic belt of Iran: new data and interpretations. Tectonophysics 229, 211-238.

Alavi, M., 2004. Regional stratigraphy of the Zagros fold-thrust belt of Iran and its proforeland evolution. American Journal of Science 304, 1-20.

Alexander, B.W., Bau, M., Andersson, P. \& Dulski, P., 2008. Continentally derived solutes in shallow Archean seawater: rare earth element and $\mathrm{Nd}$ isotope evidence in iron formation from the 2.9 Ga Pongola Supergroup, South Africa. Geochimica et Cosmochimica Acta 72, 378-394.

Aliyari, F., Rastad, E. \& Mohajjel, M., 2012. Gold deposits in the Sanandaj-Sirjan zone: orogenic gold deposits or intrusion-related gold systems? Resource Geology 62, 296-315.

Barrett, T.J., Jarvis, I. \& Jarvys, K.E., 1990. Rare earth element geochemistry of massive sulfides-sulfates and gossans on the Southern Explorer Ridge. Geology 18, 583-586.

Bodnar, R.J., 1999. Hydrothermal solutions. [In:] C.P. Marshall \& R.W. Fairbridge (Eds): Encyclopedia of geochemistry. Kluwer Academic Publishers, Lancaster, 333-337.

Bodnar, R.J. \& Vityk, M.O., 1994. Interpretation of micro thermometric data for $\mathrm{H}_{2} \mathrm{O}-\mathrm{NaCl}$ fluid inclusions. [In:] B. De Vivo \& M.L. Frezzotti (Eds): Fluid inclusions in minerals - methods and applications. Virginia Tech, Blacksburg, 117-130.

Bozkaya, G. \& Gökce, A., 2004. Trace- and rare-earth elements geochemistry of the Karalar (Gaipasa-Antalya) barite-galena deposits, Southern Turkey. Turkish Journal of Earth Sciences 13, 63-75.

Burton, J.D., Culkin, F. \& Riley, J.P., 1959. The abundances of gallium and germanium in terrestrial materials. Geochimica et Cosmochimica Acta 16, 151-180.

Chen, D., Qing, H., Yan, X. \& Li, H., 2006. Hydrothermal venting and basin evolution (Devonian, South China): constraints from rare earth element geochemistry of chert. Sedimentary Geology 183, 203-216.

Clark, H.B, Poole, F.G. \& Wang, Z., 2004. Comparison of some sediment hosted, stratiform barite deposits in China, the United States, and India. Ore Geology Reviews 24, 85-101.

Darvishi, E., 2011. Petrology of volcanic rocks in South Azna. [In:] The International Conference on Geology, Geotechnology and Mineral Resources of Indochina (GEOINDO 2011, Khon Kaen, Thailand, Theme 1 : Geology E mineral resources), 16-21.

Ehya, F., 2012. Rare earth element and stable isotope (O, S) geochemistry of barite from the Bijgan deposit, Markazi Province, Iran. Mineralogy and Petrology 104, 81-93.

Ghasemi, A. \& Talbot, C.J., 2006. A new tectonic scenario for the Sanandaj-Sirjan zone (Iran). Journal of Asian Earth Sciences 26, 683-693.

Ghorbani, M., 2002. An introduction to economic geology of Iran. National Geoscience database of Iran (Tehran), 695 pp. (in Farsi).
Gökce, A. \& Bozkaya, G., 2008. Fluid inclusion and stable isotope characteristics of Karalar (Gaipasa-Antalya) barite-galena deposits, Southern Turkey. Geology of Ore Deposits 50, 145-154.

Griessmann, M., Mumm, A.S., Seifert, T. \& Conor, C., 2010. The Mt. Mulga barite magnetite copper gold mineralisation, Olary Domain, South Australia. Journal of Geochemical Exploration 106, 110-120.

Griffith, E.M. \& Paytan, A., 2012. Barite in the ocean-occurrence, geochemistry, and palaeoceanographic applications. Sedimentology 59, 1817-1835.

Guichard, F., Church, T.M., Treuil, M. \& Jaffrezic, H., 1979. Rare earths elements in barites: distribution and effects on aqueous partitioning. Geochimica et Cosmochimica Acta 49, 983-997.

Hein, J.R., Zierenberg, R.A., Maynard, J.B. \& Hannington, M.D., 2007. Barite-forming environments along a rifted continental margin, southern California borderland. Deep Sea Research part II: Tropical Studies in Oceanography 54, 1327-1349.

Jébrak, M., El Wartiti, M., Marcoux, E. \& Zaharoui, M., 2011. The Bouznika Cambrian barite deposit (Morocco), an early mineralization on the Iapetus margin. Journal of African Earth Sciences 60, 53-62.

Jewell, P.W \& Stallard, R.F., 1991. Geochemistry and paleoceanographic setting of central Nevada bedded barites. Journal of Geology 99, 151-170.

Jurković, I., Garašić, V. \& Hrvatović, H., 2010. Geochemical characteristics of barite occurrences in the Palaeozoic complex of south-eastern Bosnia and their relationship to the barite deposits of the mid-Bosnian Schist Mountain. Geologia Croatica 63, 241-258.

Jurković, I.B., Garašić, V. \& Jurković, I.M., 2011. Geochemical characteristics of mercurian, tetrahedrite, barite and fluorite from the Duboki Vagan, Glumac and Dubrave-Dugi Dol barite deposits, south of Kresevo, mid-Bosnian Schist Mts. Geologia Croatica 64, 49-59.

Kato, Y. \& Nakamura, K., 2003. Origin and global tectonic significance of early Archean cherts from the Marble Bar greenstone belt, Pilbara Craton, Western Australia. Precambrian Research 125, 191-243.

Kelley, K., Dumoulin, J.A. \& Jennings, S., 2004. The Anarraaq $\mathrm{Zn}-\mathrm{Pb}-\mathrm{Ag}$ and barite deposit, northern Alaska: evidence for replacement of carbonate by barite and sulfides. Economic Geology 99, 1577-1591.

Kesler, S.E., 2005. Ore-forming fluids. Elements 1, 13-18.

Levinson, A.A., 1974. Introduction to exploration geochemistry. Applied Publishing Ltd., Calgary, 612 pp.

Lottermoser, B.G. \& Ashley, P.M., 1996. Geochemistry and exploration significance of ironstones and barite-rich rocks in the Proterozoic Willyama Supergroup, Olary Block, South Australia. Journal of Geochemical Exploration 57, 57-73.

McDonough, W.F. \& Sun, S.S., 1995. The composition of the earth. Chemical Geology 120, 223-253.

Mohajjel, M., Fergusson, C.L. \& Sahandi, M.R., 2003. Cretaceous-Tertiary convergence and continental collision, Sanandaj-Sirjan Zone, Western Iran. Journal of Structural Asian Earth Sciences 21, 397-412. 
Molinaro, M., Leturmy, P., Guezou, J.C., de Lamotte, D.F. \& Eshraghi, S.A., 2005. The structure and kinematics of the southeastern Zagros fold-thrust belt, Iran: from thin-skinned to thick-skinned tectonics. Tectonics 24, 1-19.

Murray, R.W., 1994. Chemical criteria to identify the depositional environment of chert: general principles and applications. Sedimentary Geology 90, 213-232.

Murray, RW., Buchholtz ten Brink, M.R., Jones, D.L., Gerlach, D.C. \& Russ III, G.P., 1990. Rare earth elements as indicators of different marine depositional environments in chert and shale. Geology 18, 268-271.

Noguchi, T., Shinjo, R., Ito, M., Takada, J. \& Oomori, T., 2011. Barite geochemistry from hydrothermal chimneys of the Okinawa Trough: insight into chimney formation and fluid/sediment interaction. Journal of Mineralogical and Petrological Sciences 106, 26-35.

Safaei, H., 2009. The continuation of the Kazerun fault system across the Sanandaj-Sirjan Zone (Iran). Journal of Asian Earth Sciences 35, 391-400.

Soheili, M., Jafarian, M.B. \& Abdullah, M.R., 1992. Geological map of the Aligudarz area 1:100 000. Geological Survey of Iran, Tehran.
Shepherd, T.J., Ranbin, A.H. \& Alderton, D.H.M., 1985. A practical guide to fluid inclusion studies. Blackie, Glasgow, $239 \mathrm{pp}$

Torres, M.E., Bohrman, G., Dube, T.E. \& Poole, F.G., 2003. Formation of modern and Paleozoic stratiform barite at cold methane seeps on continental margins. Geology 31, 897-900.

Ulrich, M.R. \& Bodnar, R.J., 1988. Systematics of stretching of fluid inclusions II: barite at $1 \mathrm{~atm}$ confining pressure. Economic Geology 83, 1037-1046.

Yeganeh, B.Y., Feiznia, S. \& van Loon, A.J., 2012. Sedimentary environment and palaeogeography of the ?Palaeocene-Middle Eocene Kashkan Formation, Zagros fold-thrust belt, SW Iran. Geologos 18, 13-36.

Zarasvandi, A.R., Charchi, A., Carranza E.J.M. \& Alizadeh, B., 2008. Karst bauxite deposit in the Zagros mountain belt, Iran. Ore Geology Reviews 32, 521-532.

Manuscript received: 21 June 2013

Revision accepted: 7 July 2014 